\title{
Struggles for African independent education and land rights on the Rand and the significance of the Tsewu court case, 1903-1905: A new analysis
}

\author{
Vusumuzi R. Kumalo*
}

\begin{abstract}
The years between 1886 and 1910 were among the most dramatic in the history of southern Africa. Scholars have documented Johannesburg's urban history and racial politics during this period. What has often been overlooked, however, and which this article draws attention to in a fresh analysis, is the connection between the colonial state's limitation of African rights to land ownership and the development of the struggle for an independent system of education for Africans. At the local level, this broader struggle was expressed explicitly in African discontent at municipal administrative failure to address the issues of adequate sanitation, land rights, tenure security, and prospects for upward mobility. This article argues that it is in a reassessment of the significance of the 1905 litigation initiated by Reverend Edward Tsewu which provides a basis for this new inquiry into the connection between the African struggle for property rights and independent education.
\end{abstract}

Key words: Land ownership; education; independent churches; South Africa; Edward Tsewu.

\section{Opsomming}

Die jare 1886-1910 in suider-Afrika kan waarskynlik beskou word as 'n tydperk van belangrike mylpaalgebeure wat die geskiedenis van die streek op 'n dramatiese wyse beïnvloed het. In hierdie tydperk het akademici die stadsgeskiedenis en rassepolitiek van Johannesburg begin dokumenteer. Wat egter soms die oog en historiese debat ontgaan, is die verband tussen die inperking van Afrikane se reg op grondbesit, en die stryd om 'n selfstandige onderwysbestel vir swart Suid-Afrikaners in te stel. Plaaslik was hierdie stryd te verbind met 'n ontevredenheid oor administratiewe mislukkings op munisipale vlak. Sake soos sanitasie, grondregte, eiendomsbeveiliging en gebrekkige vooruitsigte vir sosio-ekonomiese bevordering het hierdie ontevredenheid versterk. 'n Herbeoordeling

\footnotetext{
Vusumuzi "Vusi" Kumalo is a lecturer at Nelson Mandela University. He has published papers on the politics of knowledge production and economic history. Along with Benjamin Lawrance, he recently edited the latest edition (2020) of the novel by Dugmore Boetie, Familiarity is the Kingdom of the Lost, published by Ohio University Press. Kumalo is the author of From Plough to Entrepreneurship: A History of African Entrepreneurs in Evaton 1905-1960s (2020). Acknowledgement goes to Clive Glaser, Liz Thornberry, and Benjamin Lawrance for their comments on aspects of this article.
}

\footnotetext{
How to cite this article: V. Kumalo, "Struggles for African independent education and land rights on the Rand and the significance of the Tsewu court case, 1903-1905: A new analysis", Historia, 65, 1, May 2020, pp 14-37. 
van die regsgeding in 1905, geïnspireer deur eerwaarde Edward Tsewu, vorm die basis vir 'n herbesinning van die verband tussen die stryd om eiendomsreg deur swart bewoners van Suid-Afrika, en die stryd vir'n selfstandige sendingonderwys.

Sleutelwoorde: Grondbesit; opvoedkunde; onafhanklike kerke; Suid-Afrika; Edward Tsewu.

\section{Introduction}

After the South African War (1899-1902), Alfred Milner, the governor of the Cape and high commissioner of South Africa, set out to bring order to the Johannesburg metropolis. The Milner government's efforts to control African urbanisation and to curtail "racial mixing" encountered resistance from black urbanites, particularly the educated elite who belonged to the Ethiopianist movement. ${ }^{1}$ Many scholars have documented Johannesburg's urban history and racial politics during the post-war reconstruction government. ${ }^{2}$ What has often overlooked, however, is the connection between the limitations placed on African rights to land ownership and the struggle for independent African education.

It is the central argument of this article that while it was at the local level that African discontent at municipal administrative failures regarding sanitation, land rights, tenure security and prospects for socio-economic advancement were most visible, important connections must be made with the struggles of mission educated Ethiopianist leaders, such as Reverend Edward Tsewu, Reverend Jantjie Zachariah (J.Z.) Tantsi, Reverend Mangena Mokone, and many others. This group responded to land dispossession and colonialisation. They focused on gaining political rights for Africans in the new colonial society of South Africa. ${ }^{3}$ Moreover, the article argues that the Reverend Edward Tsewu, a minister of the African Methodist Episcopal Church (AMEC), who emerged as the most significant leader of this struggle in the early

1. The Ethiopianist movement was a religious movement among sub-Saharan Africans that embodied the earliest stirrings toward religious and political freedom in the modern colonial period. Other members of this movement were also members of the Transvaal Native Congress (TNC) and the Transvaal Vigilance Association (TVA). For example, Reverend Edward Tsewu led the vigilante organisation called Iso Lomzi. See A. Odendaal, Vukani Bantu, The Beginning of African Protest Politics to 1910 (David Philip, Cape Town, 1984), pp 144-145.

2. See, L. Callinicos, A Place in the City: The Rand on the Eve of Apartheid (Ravan Press, Johanneburg, 1993), pp 1-15; P. Bonner, "The Transvaal Native Congress, 1917-20: The Radicalisation of the African Petty Bourgeoisie on the Rand", in S. Marks and S. Trapido (eds), Industrialisation and Social Change in South Africa (Longman, London, 1982), pp 270-273; and P. Bonner, "African Urbanisation on the Rand in the 1950s and 1960s: Its Social Character and Political Consequences", Journal of Southern African Studies, 21, 1, 1995, pp 115-116.

3. On Tantsi, see T.D. Mweli-Skota (ed.), The African Yearly Register: An Illustrated National Biographical Dictionary (Who's Who) of the Black Folks in Africa (L. Esson, Johannesburg, 1930). With decades long gaps, the book does not provide enough material for a biography of Tantsi. 
twentieth century for land rights in South Africa. By re-assessing the significance of the litigation against the Crown Government initiated by the Reverend Edward Tsewu, this article demonstrates the centrality of the mid-Victorian liberal programme of advancement, which was tightly linked to the question of education, in the struggle for land rights in the period between 1903 and 1905 on the Witwatersrand.

From the 1890s to the early 1900s, African reserves such as that at Inanda, an African reserve northwest of Durban, allowed educated Africans like Dr John Langalibalele Dube to build the Ohlange Institute, the first African-led school in Natal, without any legal hinderance. African independent churches on the Rand found it difficult, however, to purchase land to build independent schools for the children of Africans who had settled there permanently. Before the discovery of gold, land was in the hands of the Afrikaner people in the Transvaal. Africans were technically without any land and were dependent on the Afrikaner authorities to demarcate locations for them. They were only allowed to live in these locations on condition of good behaviour; they were not permitted to own the land directly with title deeds. ${ }^{4}$ According to Stanley Trapido, it was this that "led to rapid [capital] accumulation among Afrikaner notables ... [However] the major source of profit from agriculture ... lay in the various forms of rent paid by Africans". 5

In an attempt to generate revenue, the government of the Zuid-Afrikaansche Republiek (ZAR) bought the south-eastern portion of the farm Braamfontein in 1887. The aim was to demarcate the Braamfontien stream, a river that flowed through the farm, and to sell water to the residents of Johannesburg. Along the stream there were also large quantities of clay, suitable for brickmaking. The government decided that money was to be made from issuing brick makers' licences at five shillings per month. ${ }^{6}$ The result was that many landless Dutch-speaking burghers (citizens) of the ZAR settled on the property and started making bricks. They also erected shacks there to live in. Soon, the area was known either as Brickfields or as Veldschoendorp. ${ }^{7}$ Soon thereafter, African workers and Indians also settled there.

As Johannesburg's formal boundaries began to expand beyond the original Randjeslaagte triangle, the brickfields soon became an attractive site for municipal planners wishing to secure a convenient location for black South Africans and Indians. ${ }^{8}$ In 1893, parts of the Brickfield locations were established under the Kruger

4. J. Bergh and H.M. Feinberg, "Trusteeship and Black Land Ownership in the Transvaal during the Nineteenth and Twentieth Centuries", African Historical Review, 36, 1, 2004, p 175.

5. S. Trapido, "Introduction to Reflections on Land, Office and Wealth in the South African Republic, 1850-1900", Historia, 53, 2008, p 24.

6. E.L.P. Stals, Afrikaners in die Goudstad (Van Schaik, Pretoria, 1978), pp 1-6.

7. C. van Onselen, New Babylon: New Nineveh (Johathan Ball, Johannesburg, 2001), pp 319-321.

8. B. Keith, Johannesburg: The Making and Shaping of the City (UNISA Press, Pretoria, 2004), pp 72-78. 
government, and were reserved for occupation by "non-whites". In government parlance, these three locations were named the "Coolie Location" (where most of the residents were of Asian descent), the "Kaffir Location" (where Africans lived) and the "Malay Location" (where Cape Malays settled). ${ }^{9}$

This was where Africans who were thirsty for education settled. It was also where the related struggles for landownership and independent education were waged. A new wave of immigration that had been sparked by the gold rush in 1886 had also attracted Africans who, as historian James Campbell puts it, were

... turned out of [mission] schools, cursed with the rudiments of an education which suffices only to make them despise manual labour as degrading. Crammed as they are with a knowledge which fades like a breath on a looking, they drifted to cities and towns in search for employment. ${ }^{10}$

This frustration at the low standard of education provided momentum for African-led education on the Rand.

Under the leadership of Reverend Edward Tsewu, a group of mission-educated Africans mobilised to challenge restrictions on African land ownership in the Transvaal. Importantly, they were joined in this endeavour by black women and men who had not received formal education. Born in Grahamstown in 1856, Tsewu was the son of one of the deacons of the Lovedale Institute. From 1880 to 1883, he attended theological classes at Lovedale. He was licensed by the Free Church Mission Presbytery of Kaffraria in 1884. Thereafter he went to work at Tholeni Station during the absence of a designated missionary. Two years later, he was transferred to Idutywa where he worked until the late 1880s.

Tsewu was then transferred to Johannesburg, and although his work appeared successful, some of his congregation accused him of financial irregularities. He then broke away to form an Independent Presbyterian Church in Johannesburg. His church did not, however, last beyond 1905. Tsewu then became a priest in the African Methodist Episcopal Church (AMEC). ${ }^{11}$ The AMEC is an African denomination that was founded on racial rather than theological distinction in the United States (US) and South Africa in the late nineteenth century. This church advocated persistently for the civil and human rights of Africans both in the US and Africa through social improvement, religious autonomy and political engagement. It was at this time in his Independent Presbyterian Church that Tsweu became involved with litigation against

9. Keith, Johannesburg: The Making and Shaping of the City, pp 72-78.

10. J. Campbell, The Songs of Zion: The African Methodist Episcopal Church in the United States and South Africa (Oxford University Press, Oxford, 1998), p 146.

11. G.A. Duncan, "Pull up a good tree and push it outside? The Rev Edward Tsewu's Dispute with the Free Church of Scotland Mission", NGTT, 53, 1 and 2, pp 50-61 at http://ngtt.journal.co.za Accessed 27 August 2018, pp 59-60. The NGTT, formerly the Nederduitse Gereformeerde Teologiese Tydskrif (1959-2014), is now known as the Stellenbosch Theological Journal (ST). 
the Crown Government on the matter of land tenure rights. It was also during this period that he carried out grassroots support for the upliftment of local residents after the South African War (1899-1902).

From the late 1890s, and more particularly the early 1900s, the educated elite, many of them teachers and organisers of the independent schools, were keen to own and register land in their names in different locations on the Rand. There were those who were fortunate enough to buy land, but could only register the transfer of the property from the previous owner in the name of a white person, especially a missionary or, after 1880, a public official, who would then hold the property "in trust" for the real buyers. After the South African War, the pressing demand for land where Africans could settle and build their own churches and schools intensified. It became increasingly apparent that issues of African land tenure rights had to be pursued proactively.

Drawing on British colonial notions of landholding based on freehold titles, Tsewu and his companions began to discuss and debate the issues of land and independent schools extensively in 1904.12 In addition, they fought for freehold rights. As can be seen in the following discussion, these African converts confronted a formidable set of constraints and barriers far different from the life of the African in the liberal Cape. The hostility of the government and uncompromising mode of engagement by Tsewu and his peers attracted the attention of the landless ordinary urban wage labourers and former sharecroppers who came to the Rand independently of the mine recruiting organisations, often bringing their families with them.

Following Tsewu's court victory in 1905, various independent African missionary schools were established on the Rand, the most prominent being the Wilberforce Institute, the first and largest African controlled teacher-training, seminary and combined school, established by the AMEC in Evaton in 1905. ${ }^{13}$ For Tsewu's movement, the African struggle for land was not only about land needed for grazing and food production, but also for educational purposes. ${ }^{14}$

Influenced by Cape liberalism, Tsewu and his mission-educated comrades linked the struggle for African independent education with the colonial notions of landholding based on freehold titles. In some respects, they were trying to recreate

12. L.F. Braun, Colonial Survey and Native Landscapes in Rural South Africa, 1850-1913 (Brill, London, 2014), pp 346-347; and Campbell, The Songs of Zion, pp 154-155.

13. V.R. Kumalo, "The African Struggle for Independent Education: A History of Wilberforce Institute, Evaton 1905 to 1950s", PhD thesis, University of the Witwatersand, 2018, pp 122-123.

14. In this context, literacy was an important weapon because not only could it take the struggle beyond local, regional, and even national boundaries, but also because reading informed the ideological discourse from which a new African nationalist movement grew. Reading also gave access to the literature on the black civil rights movement in the US. The writings of key thinkers such as Booker Washington and W.E.B. du Bois were already circulating among the African elite in South Africa by 1900. 
aspects of the Cape educational and landholding regime on the Rand, where those Africans who had accepted Christianity and acquired literacy and canonical European literature would be treated as equal, modern citizens. Yet, far from alienating mission-educated Christians from the rest of Johannesburg's black population, as James Campbell suggests, the urban African intelligentsia reached quite deeply into urban communities. ${ }^{15}$ They addressed local issues that impinged on the lives of all urban classes, especially in the years after the South African War. As part of their African Methodist mission, they offered direction, discipline and education, which was a precious resource, and was the only thing that separated a respectable clerk and a non-Christian educated urbanite. ${ }^{16}$ Given the urban need for education, the struggle for land and education tied the interests of mission-educated Africans to those of non-Christians in ways that historians have not previously fully recognised.

By focusing on the grassroots movement that undergirded the pre-1905 struggle for land tenure rights in the Transvaal, this article offers a new and alternative narration of the history of the African struggle for land rights in South Africa. Taking Tsewu's case into account, it highlights the various struggles over land that developed over time in different historical contexts. Further, it recognises that the struggle for land is a dynamic process, and highlights the ways in which these complex struggles played out in different contexts of the nineteenth and early twentieth century. This process also draws attention to different forms of land access and use. In seeking ways to navigate and understand the pre-1910 struggle, the first part of this article pays special attention to the Tsewu court case and reviews the burgeoning literature on the complexities of land tenure rights after the South African War on the Rand. The second part of the paper focuses on issues of education and access to land as inspired by Cape liberalism.

\section{Tsewu v. Registrar of Deeds and the African struggle for land tenure}

As already stated, the African struggle for ownership of land in South Africa went through different phases from the middle of the nineteenth century until 1905, and thereafter. In the early twentieth century, discriminatory land laws in the Transvaal prohibited Africans from buying and registering land. Unlike the situation in the British colonies of the Cape and Natal, where Africans enjoyed freehold property rights prior to 1905, Africans in the Transvaal were technically prohibited from registering land in their own name. ${ }^{17}$ They could only own land under trusteeship, a system that permitted missionary societies or male white individuals and companies to serve as intercessors. These white agents were legally permitted to buy land on behalf of landless Africans. ${ }^{18}$

15. Campbell, The Songs of Zion, pp 150-152.

16. Campbell, The Songs of Zion, pp 148-152.

17. W. Beinart and P. Delius, The Historical Context and Legacy of the Natives Land Act of 1913, Journal of Southern African Studies, 40.4 , 2014, p 669. See also Bergh and Feinberg, "Trusteeship and Black Land Ownership in the Transvaal”, pp 171-172.

18. Bergh and Feinberg, "Trusteeship and Black Land Ownership in the Transvaal, pp 171-173. 
In what has become a well-known milestone in histories of the liberation struggle, Reverend Edward Tsewu set out to challenge the restrictions of African land ownership. ${ }^{19}$ This raises the question of whether Tsewu set out to challenge the Crown government and its restrictions on behalf of all Africans, or whether his initial aim was to solve his specific personal circumstances. Building on this, the following discussion highlights how his movement became a wider, as well as a consciously broad-based and political challenge.

In 1904, Tsewu bought a freehold stand, Lot. No. 5, situated in Klipriviersoog Estate (a farm where the town known as Kliptown was subdivided) from Henri Rocke Murray. As a seller, Rocke Murray signed all the necessary documents and executed all the deeds required for legal transfer. In an attempt to register his property under his own name, Tsewu tendered the transfer of his stand to the Office of the Registrar of Deeds in Pretoria for registration. ${ }^{20}$ In response, however, his request was refused on the grounds that Tsewu was an African and that the laws of the Transvaal did not permit Africans to register land. In his report, the registrar wrote:

The reason why I would refuse to register transfer in the name of Edward Tsewu is that I presume he is a native (natural or inboorling) both of whose parents were members of the aboriginal tribes of South Africa and that as such he is debarred from holding land in his own name. My authority for so refusing to register transfer is art 106 of Volksraad minutes of 14 August 1884.21

This was an early attempt in Transvaal history of a native of African origin applying for property to be registered in his name at the Deeds Office in Pretoria. Tsewu's application was refused, but he persisted in his efforts to have his property registered. In an appeal to the Transvaal Commissioner for Native Affairs, Tsewu wrote:

I am instructed by my Committee to beg, to submit the following points ... is there a law in existence now in this Colony prohibiting native British subjects owning land to register in their own names? If so, we beg to approach Sir Godfrey Lagden as our representative to go with us in approaching His Excellency the Lieutenant Governor to repeal such a law.22

On 8 July 1904, Commissioner Lagden met with Tsewu and his committee. This team comprised mission educated African evangelists who had broken away from the mainstream churches. Among them were Reverends Mangena Mokone, Marcus Gabashane, Zachariah Tantsi, James Ngubane, Simon Sinamela, John Mtshula and

19. H.M. Feinberg, "Black South African Initiatives and the Land, 1913-1948", Journal of Contemporary History, 34, 2, 2009, pp 40-42.

20. Bergh and Feinberg, "Trusteeship and Black Land Ownership", pp 170-174.

21. National Archives of South Africa, Pretoria (hereafter NASA), Secretary for Native Affairs (hereafter SNA), ZTPD 8/732 286/1905, "The affidavit of Edward Tsewu sworn before the Justice of Peace in Johannesburg", 31 March 1905.

22. NASA, SNA 226, "Letter from Edward Tsewu to Geoffrey Ladgen”, 7 July 1904. 
some ministers from the Orange River Colony. ${ }^{23}$ The most prominent leaders of the movement were the Cape-born ministers. In this the first known meeting between African location residents to air local administrative grievances and land tenure demands in the Transvaal, Lagden was unsympathetic to their demands. He advised Tsewu and his committee, who threatened to take legal action, that they should not go to the Supreme Court because this action would strain relations and bring the committee into what he termed "undesirable relations with Europeans". ${ }^{24}$

Lagden believed that Tsewu and his committee, the church leaders who were largely Ethiopianists, had been misled by lawyers and were "doing things which they will afterwards regret". ${ }^{25} \mathrm{He}$ defended Resolution 159 adopted by the Republican government of the Transvaal in 1855 which endorsed that Africans should not be allowed to enter the market and buy land. ${ }^{26}$ Moreover, Ladgen felt that white people should hold titles in trust for aspirant African buyers "so as to protect [African] owners against unscrupulous speculators and others who would only be too ready to take every advantage of their ignorance". ${ }^{27}$ Typical of the time, his proposal was characterised by white paternalism which aimed to limit African rights to land ownership and undermine the social and political maturity of aspirant African landowners. By its very nature, state trusteeship was designed to establish firm state control over the disposal of land and, of equal importance, mineral rights.

Despite Lagden's warnings, Tsewu and his committee pursued legal action. After several unproductive meetings with officials from the Department of Native Affairs, they decided to commission Mr Williamson, an attorney, to file a court application on behalf of Tsewu. After the court hearing, the presiding judge granted the applicant (Tsewu) the right to register his property in his name. ${ }^{28} \mathrm{~A}$ newspaper narrated Tsewu's victory as follows:

After hearing $\mathrm{Mr}$ Williamson the representative Counsel for Tsewu and $\mathrm{Mr}$ Burns-Beggs the state representative... the court held that neither the Volksraad Resolution of the 14th August 1884 nor Article 13 of the London Convention upon which the Registrar of Deeds based his refusal, prohibited natives from holding land in their own names. ${ }^{29}$

\footnotetext{
23. Campbell, The Songs of Zion, p 154.

24. NASA, SNA 226, "Letter from Edward Tsewu to Geoffrey Ladgen”, 7 July 1904.

25. NASA, SNA 226, "Letter from Edward Tsewu to Geoffrey Ladgen', 7 July 1904. As a priest who broke away from the Presbyterians, he was favoured by the group of Ethiopianists and his influence was backed strongly by other church members. See, Duncan, "Pull up a good tree and push it outside", pp 59-61.

26. I. Omar, "The Group Areas Act: A Historical and Legal Review”, De Rebus, 1989, p 515; and Bergh and Feinberg, "Trusteeship and Black Land Ownership", pp 172-173.

27. NASA, SNA 226, Untitled, undated report.

28. NASA, SNA 226, Untitled report.

29. NASA, SNA 226, Newspaper cutting entitled Supreme Court (undated).
} 
The Tsewu court case decision opened up the opportunity for Africans to buy farms more easily. Between 1905 and 1913, Africans purchased approximately 400 farms. During this time, buyers had the choice of registering the transfers in their own names or of continuing to use the in trust system. ${ }^{30}$ This legal victory also led to the foundation of the Wilberforce Institute in 1905 under the direction of Reverend Jantjie Zachariah Tantsi in the Rand freehold township of Evaton.

\section{Historical scholarship and land tenure rights in South Africa: towards a reassessment}

Tsewu's court victory has become a landmark in the debate on African ownership of land in the former Transvaal, and in the substantial literature on land rights, Tsewu's legal struggle looms large. ${ }^{31}$ In these accounts, however, Tsewu is seen as emblematic of a cohort of mission-educated Africans and their contributions to the rise of African nationalism..$^{32}$ In a recent account of the case, for example, historian Jacob Dlamini writes that "Tsewu and his comrades were not fighting for every African to have the right to own property but rather only for those Africans they believed qualified and had the means to own property in their individual capacities". ${ }^{3}$ Characteristic of this line of analysis, Dlamini treats the mission-educated individuals as a distinct group, contrasting them with non-Christians still caught up in the remnants of the rural order.

Dlamini identifies Tsewu as the product of a particular intellectual and political trajectory. As a Cape-born priest, Tsewu was a "registered [land]owner in the Cape Colony, [his property was] registered in the Office of the Registr[a]r of Deeds, Kingwilliamstown ... under No. 591 Land Register". ${ }^{34}$ At that time, Cape Africans still enjoyed legal rights to own property and to live wherever they wished. In this context, Tsewu's Cape liberal background is indeed crucial and cannot be underestimated; it gave him greater confidence to challenge the racially-conscious colonial order of the Transvaal.

Tsewu was keen to acquire more properties on the Rand. He was also eager to re-create the liberal rights of the Cape's educational and landholding regime in the Transvaal. Tsewu's Cape background was not unique and Natal and Transvaal-born

30. Feinberg, "Black South African Initiatives and the Land, pp 39-41.

31. J. Walton, "Early Bafokeng Settlement in South Africa", African Studies, 15, 1956, pp 37-38.

32. On African nationalism, see A.G. Gerard, Four African Literatures, Xhosa, Sotho, Zulu and Amharic (University of California Press, Berkeley, 1971), pp 24-26; and Odendaal, Vukani Bantu, pp 3-10.

33. J. Dlamini, "The Land and its Languages: Edward Tsewu and the Pre-History of the 1913 Land Act", in B. Cousins and C. Walker (eds), Land Divided, Land Restored: Land Reform in South Africa for the 21st Century (Jacana, Johannesburg , 2015), p 32.

34. NASA, ZTPD 8/732 286/ 1905, "The affidavit of Edward Tsewu in the court case between Edward Tsewu vs Registrar of Deeds in the Supreme Court of Pretoria", 30 March 1905. 
African leaders, such as Mokone and Gabashane, also played an important political role on the Rand. As indicated, the most prominent leaders of this movement, that lasted till the formation of the South African Native National Congress (SANNC) in 1912, were the Cape-born ministers. ${ }^{35}$ For instance, both J.Z Tantsi and Tsewu were born and educated in the Eastern Cape and were graduates of Lovedale. ${ }^{36}$

Tsewu's demands for the right to landownership and equal education reflected his Cape liberal upbringing that promoted and allowed property rights. During the reconstruction period, Milner's administration did not renounce its mid-Victorian liberal outlook openly and continued to entertain African petitions and delegations. The mission-educated urban Africans continued to appeal to alleged British justice and "fair play". ${ }^{37}$ At a meeting to garner support for the court battle, for example, Tsewu outlined the crisis facing residents in the "Kaffir Location" and African people of the Transvaal. Thereafter, he read the following resolution:

\begin{abstract}
We, native inhabitants of the Transvaal Colony, emphatically protest against the legislation of the Transvaal Legislative Council with regard to registration of title deeds of landed properties acquired by natives in the name of the Commissioner for Native Affairs as it is uncalled for, as well as unnecessary. We, therefore, ask His Majesty's protection from such class of (sic) legislation by not sanctioning the Ordinance. ${ }^{38}$
\end{abstract}

Describing the historical origins of the law that regulated the African right to land ownership, Tsewu emphasised that it was contrary to British liberal traditions. ${ }^{39}$ Historians should, however, be wary of assuming that mission-educated Africans, including Tsewu, were not representative of the broader population of urban residents. This was so, I argue, despite the rhetoric of Native Affairs officials, who described Tsewu as not "representing native opinion or the natives of the Transvaal". These officials went on to claim that he was merely the leader of a "very small disaffected section in Johannesburg, [was] ... not a Transvaal native...[and was] scarcely known, and [that his efforts and influence carry] no weight". 40 Commissioner Lagden believed that education separated Tsewu and his peers from the African masses, telling them:

You [educated residents]... have been learning for a long time before you could come and speak to me in such good English and you are a long way ahead of the majority of the people. I have to consider the great mass of people. You only represent a very small section of educated elites. ${ }^{41}$

35. R. Davis-Hunt, "Nineteenth Century African Education in the Cape Colony: A Historical Analysis", PhD thesis, University of Wisconsin, 1969, pp 30-32.

36. Odendaal, Vukani Bantu, p 53.

37. Campbell, The Songs of Zion, p 149.

38. Resolution read by Tsewu at a meeting held on 15 February 1905.

39. Campbell, The Songs of Zion, pp 154-155.

40. NASA, SNA 226, Native Acquisition and Tenure of Land, 1905.

41. NASA, SNA 226, Notes of interviews between the Commissioner for Native Affairs and Tsewu's Committee, 8 July 1904. 
By contrast, archival evidence strongly suggests that Tsewu's land campaign had significant popular support. Ever since the 1890s, regular meetings that formulated plans for solutions to the pressing problems facing residents of the "Kaffir Location", were held in an open space called ecibini (the lake) at the time when the pass laws intensified. ${ }^{42}$ At these meetings, people spoke from the heart about local social problems. This is where the educated residents of the township embraced the wider community, particularly non-Christians and uneducated inhabitants. Building on midVictorian Cape liberalism, the meetings derived from fundamental liberal premises without any fear of prejudice and discrimination. It was through these gatherings that Africans were able to share their political views on issues ranging from pass laws to laws governing urban locations. In structure, the meetings were blended with the traditional lekgotla system, in that they strengthened the bonds of all family representatives and provided an opportunity for every male member of the community to participate. ${ }^{43}$

In 1905, Tsewu used one such ecibini (the lake) meeting to garner political and financial support for his ongoing court litigation. Attendees agreed unanimously to adopt a resolution that "a private cable should be sent to representatives in England, informing them of the resolution and asking them to watch proceedings on behalf of the natives of the Transvaal". ${ }^{44}$ Residents of the location also made financial contributions towards Tsewu's legal case. Among the contributors were displaced sharecroppers and dispossessed peasants who, after Tsewu's legal victory, were able to buy properties of their own in freehold areas of Evaton (founded in 1905), Kliptown (founded in 1903), Alexandra (founded in 1912) and Sophiatown (founded in 1905). This class of residents came from a number of dismantled rural communities where socio-economic respectability was based on land ownership and its cultivation. ${ }^{45}$

42. NASA, SNA 287, James Ngubane, Statement read before the Justice of the Peace, 24 November 1905.

43. The word lekgotla originates from the Tswana-Sotho language; it means a meeting place or a meeting for village assemblies, court cases, and meetings of village leaders.

44. NASA, SNA 226, Notes of interviews between the Commissioner for Native Affairs and Tsewu's Committee, 8 July 1904.

45. On the rise and fall of the rural economy, see C. Bundy, The Rise and Fall of the South African Peasantry (David Philip, Cape Town, 1979); C. Murray, Black Mountain: Land, Class, and Power in the Eastern Orange Free State, 1880s to 1980s (Edinburgh University Press, Edinburgh, 1992), pp 20-25; T. Keegan, Rural Transformation in Industrialising South Africa: The Southern Highveld to 1914 (Macmillan, London, 1987); C. van Onselen, The Seed is Mine: The Life of Kas Maine, a South African Sharecropper, 1894-1985 (Jonathan Ball Publishers, Johannesburg, 1996). 
Further archival records reveal that Tsewu became influential in persuading all residents, including the uneducated section, to buy stands. ${ }^{46}$ For example, the secretary for Native Affairs, Lagden wrote: "At a recent meeting of natives in the location, Tsewu advised those present to buy stands so that when the removal of the Location takes place, they would be in a position to move to their own land." 47

Official claims that Tsewu had a "limited following" in the African section of the location were belied by the intense concern of various administrators about Tsewu's actions. Native Affairs administrators "felt that the attitude adopted by the Rev Tsewu requires to be promptly deal[t] with". ${ }^{48}$ Tsewu had a long history of what Mr Harries, the acting superintendent of the Location, described as a "man of bad character ... troublesome and insolent ... [a man who] inspired mischief against those who were carrying out the law and the government". ${ }^{49}$

The intensity of Tsewu's leadership and defiance became an interdepartmental concern to such an extent that it drew the attention of the Johannesburg City Council, the colonial Department of Justice and the Department of Native Affairs. In discussion between the commissioner for Native Affairs and Harries, the superintendent of the location, Harries described Tsewu as "spreading discontent among the natives and doing his utmost to destroy their confidence in the government". ${ }^{50}$ Harries concluded by saying that his presence was "a menace to good order [and] management of the Location". As a result, drastic steps to expel Tsewu from the Transvaal were taken. ${ }^{51}$ This official instruction was, however, overruled by the legal decision of the attorney general, who referred to the fact that "the power of ejection" was not stated in Section 13 of the eviction laws. ${ }^{52}$ Even so, these efforts to expel Tsewu convey the underlying concern among government officials that Tsewu's influence went beyond that of a small stratum of highly educated Africans.

46. In NASA's SNA Collection there are many relevant documents on the meetings held. On their context, see C. Page, "Black America in White South Africa: Church and State Reaction", PhD thesis, University of Edinburgh, 1978, pp 1-8; and Mweli-Skota, African Yearly Register, which illustrates the African urban elite's claim to leadership as a political group. This rested on its facility with colonial strategies and rituals such as the petition and deputation. The urban elite of Tsewu's generation was preoccupied with "leadership" and discussed it in numerous articles in the black press. See for example those published in Imvo Zabantsundu and Umteteleli Wabantu.

47. NASA, SNA 287, Secretary for Native Affairs. Letter from the Secretary for Native Affairs to His Excellency the Lieutenant Governor, 1 December 1905.

48. NASA, SNA 287, Letter from the Secretary for Native Affairs to the Lieutenant Governor, 17 November 1905.

49. NASA, SNA 287, Commissioner for Native Affairs and report on discussions with Harries (undated).

50. NASA, SNA 287, The Commissioner for Native Affairs (undated).

51. NASA, SNA 287, The Commissioner for Native Affairs (undated).

52. NASA, SNA 287, The Commissioner for Native Affairs (undated). 
This evidence, I argue, invites a reconsideration of the links between educated and un-educated Africans in the urban Transvaal, particularly in relation to the question of land. Hitherto, the considerable scholarly debate on land dispossession and urbanisation has focused on how educated Christian and non-Christian residents of the Rand experienced oppressive conditions collectively in both urban and rural areas. $^{53}$ Indeed, migration to urban areas was the outcome of land dispossession and taxation. Other scholars highlight how their traumatic experiences obliged many rural Africans to abandon subsistence agriculture altogether. ${ }^{54}$ Desspite linguistic differences, class and regional backgrounds, the new urbanised community of the location shared common experiences of racial oppression, segregation, displacement, and dispossession; they fostered a determination to forge a new urban identity. Moreover, their shared aspiration for education aspiration embued them to support the struggle for land ownership. Studies of the freehold areas of the Rand reveal that the urban struggle for land tenure, as evidenced by the Tsewu case, was equally relevant to displaced Africans regardless of their educational status. Its aim was to assist the majority of uneducated African urban dwellers and displaced rural farmers. ${ }^{55}$

\section{Education in the Native Location, Johannesburg, 1904-1905}

While the struggle for individual land rights is widely recognised as central to the liberation struggle, the quest for independent education has been underestimated in popular histories of South Africa. Indeed, even the substantial body of literature on the Tsewu case and the land rights movement generally, overlooks the connection between education and land rights on the Rand. However, Edward Tsewu's case marked a change in this trend.

While James Campbell notes that the AMEC ministers were responsible for local issues that impinged directly on the lives of congregants and included education and land for all urban classes, he does not explore how the urban struggle for land unfolded over time. His observation, however, suggests an unexplored question,

53. I. Donald, "Removals of a Quiet Kind: Removals from Indian, Coloured and Whiteowned Land in Natal", Carnegie Conference Paper No. 75, Southern African Labour and Development Research Unit (SALDRU), University of Cape Town, 1984; T.J.D. Fair and C. Schmidt, "Contained Urbanization: A Case Study", South African Geographical Journal, 1974, p 66.

54. A. Jeeves, Migrant Labour in South Africa's Mining Economy: the Struggle for the Gold Mines Labour Supply, 1890-1920 (McGill-Queen's University Press, Montreal, 1995) pp 1-4; A. Mabin, "The Making of Colonial Capitalism: Intensification and Expansion in the Economic Geography of the Cape Colony, South Africa, 1854-1899", PhD thesis, Simon Fraser University, 1984, pp 54-57; C. Murray, "Displaced Urbanization: South Africa's Rural Slums", African Affairs, 86, 1987, pp 311-315.

55. P. Bonner and N. Nieftagodien, Alexandra: A History (Wits University Press, Johannesburg, 2008), p 4-5; V.R Kumalo, "From Plough to Entrepreneurship: A History of African Entrepreneurship in Evaton", MA dissertation, University of the Witwatersrand, 2014, pp 1-4. 
which provides the foundation for this article. ${ }^{56}$ After the South African War, parents in the urban areas realised that education was an essential part of the path to mobility, to the achievement of aspirations in the new urban society that they were entering. They became anxious for their children to attend school. ${ }^{57}$

There were, however, very few schools that catered for African children. At the time, the urban Transvaal also had few mainstream churches that provided education, perhaps because the London Missionary Society and other missionary societies neglected that area. Even the very active Berlin Missionary Society concentrated on the rural Transvaal. It was not easy for missionaries to establish mission stations in certain parts of the rural Transvaal. Between 1861 and 1864, for instance, missionary societies set up three mission stations which fell under Sekhukhune's authority, but they were later forced to leave. ${ }^{58}$

Except for the aligned to the Dutch Reformed Church, very few missionaries began to work on the Rand in the 1890s. Although the Anglicans and others detected the opportunities that urban Johannesburg afforded for missionary work, at that time they had little interest in initiating the establishment of mission stations that would proselytise the urban "uncivilised natives". ${ }^{9}$ This being the case, in 1905 the only schools in Johannesburg and on the Rand that catered for children of colour were " 6 Government coloured schools". ${ }^{60}$ An Anglican school, St Cyprian's, founded by the Reverend John Darragh in the 1890s, was located in Brickfields and was open to all races. It was registered and subsidised by the Anglican Church. ${ }^{61}$ Like other missionary schools of the time, St Cyprian's primary purpose was to Christianise Africans and to elevate their "moral condition". ${ }^{62}$

56. Campbell, The Songs of Zion, p 153. For the context, see R.E. Phillips, The Bantu in the City: A Study of Cultural Adjustment on the Witwatersrand (Lovedale Press, Alice 1938), pp 1-10; N. Kagan, "African Settlement in the Johannesburg Area, 1903-1923", MA dissertation, University of the Witwatersrand, 1978, pp 4-8; C.T. Loram, The Education of the South African Native (Heinemann, London, 1927), pp 1-9.

57. See Phillips, The Bantu in the City; and Kagan, "African Settlement in the Johannesburg Area", pp 4-6.

58. For a detailed discussion, see E.H. Berman, "African Response to Christian Education", African Studies Review, 17, 1974, pp 527-528; J. Ball, "Imperialism, Social Control and Colonial Curriculum in Africa", Curriculum Studies, 15, 3, 1987, p 238; and M. Cross, "The Foundation of Segregated Schools in the Transvaal, 1902-1924", History of Education 16, 4, 1987, pp 259-260.

59. J.A. Hamilton, A Transvaal Jubilee: Being a history of the Church of the Province of South Africa in the Transvaal, (Society for Promoting Christian Knowledge, London 1928); P.R. Randall, "The English Private School System in South Africa", MA dissertation, University of the Witwatersrand, 1980, pp 3-4.

60. L. Chisholm, "Class and Colour in South African Youth Policy: The Witwatersrand, 1886-1910", History of Education Quarterly, 27, 1, 1981, p 14.

61. E.H. Behr, "Three Centuries of Coloured Education in the Cape and Transvaal, 16521952", PhD thesis, University of Potchefstroom, 1952, p 275.

62. University of the Witwatersrand, Historical Papers (hereafter WHP), Howard Pim Collection, A881 Fb-1, “The Report on Native Education, 1903". 
Little has been written on the racial composition of the teaching staff. Nonetheless, as the existing mission schools were sectarian, non-Anglican children were not admitted to St Cyprian's. Only children of urban parents who adhered to the Anglican faith were privileged to advance their education and move beyond illiteracy. It is unclear from the Anglican records why St Cyprian's did not admit non-Anglicans while the major sectarian missionary schools in the Eastern Cape (such as Lovedale, Healdtown, Blythswood, St Marks, and so on) accepted students of other denominations. ${ }^{63}$ Perhaps this was because there was not enough funding to provide adequately if they restricted admission to Anglican students.

On the Rand, non-Christian children who lived in the location and those from other denominations had no choice but to attend unregistered, independent schools, all of which were operated by Ethiopianists. ${ }^{64}$ These schools faced a complex mix of challenges and were not recognised by the Transvaal Department of Education. They fell under the category of "native schools", which were not eligible for a government grant and an official inspectorate. The educational ordinance and rigid municipality regulations made it difficult for these schools to access land in the municipal areas or elsewhere in the Transvaal. ${ }^{65}$ Thus, there were no prospects for African-led schools and churches to be granted freehold rights, and the attempts by Africans to own land were likely to have an unfortunate and inevitable outcome. This was recorded in the minutes of the Diocese Board of Missions when whites campaigned against African rights to land in 1905:

The action of the owners of Yeoville stands who were exchanging stands bought by the church ... were proposing to insert a new clause to make it a condition of the sale that no Kafir Church be built on them. It was suggested that a good reply to the owners of the estate would be that there was no intention of erecting any Native Church or School on the said stands. ${ }^{66}$

63. Hamilton, A Transvaal Jubilee, pp 4-6; and Randall, "The English Private School System in South Africa", pp 3-5.

64. NASA, SNA 325, NA 1644/06 and NA 1768/ 06, South African Native Affairs Commission (SANAC), Minutes of Evidence, Testimony of S.J. Mabote, the AME Church priest, p 474; SANAC, Minutes of Evidence, Testimony of Rev Farmer, p 654. See also "Letter reporting on the Maxeke school from T.J.H. Jones to the Director of Education (undated).

65. NASA SNA 325 NA 1644/06 NA 1768/ 06, SANAC, Minutes of Evidence, Testimony of S.J. Mabote, p 474; and 'Letter on the Maxeke's school from T.J.H. Jones to the Director of Education (undated). For context on these schools, see, T. Ranger, "African Attempts to Control Education in East and Central Africa 1900-1939", Past \& Present 32, 1965, pp 57-60. The Ethiopianist schools were denied financial support and access to land. In 1905, for example, Olaf Samuelson, the secretary for Native Affairs clearly stated that "... no official recognition in any other form either by grant in aid, or otherwise, shall be given to native churches independent of, and free from European control". See, Pietermaritzburg Archives (hereafter PAR), SNA 1/1/377, ref. 2587, Minister for Native Affairs.

66. WHP, AD 768, Anglican Church Collection, Minutes of the meeting of the Diocese Board of Missions, Pretoria, Friday, 9 June 1905. 
Besides, the white local municipal authorities did not grant stands to black independent churches on the Rand. This may be attributed to the mainstream missionary distaste for the success of the Ethiopianist independent church movement. ${ }^{67}$ These churches were deemed too "seditious" to be granted sites in the location. ${ }^{68}$ In addition, the mainstream missionary authorities were alarmed by the decline in their churches' membership because of the growth of African independent churches, as shown in in testimony given at the South African Native Affairs Commission (SANAC) in 1905. The London Missionary Society, for example, reported a loss of membership in 1905 due to the operations of the Ethiopianists. ${ }^{69}$

This occurred against the background of a number of secessions from mission churches for different reasons, often including issues of responsibility, consecration, exemptions and finance. ${ }^{70}$ In turn, these congregations enjoyed widespread support in the location where their schools were established..$^{71}$ The establishment of these educational institutions reflected a demand for schooling in the location that the local mission schools could not accommodate. For their continuance, not all their support was from Christian elements. Their existence was encouraged by backing from the

67. See A. Lea, "Native Separatist Churches", in J.D. Taylor (ed.), The Native Separatist Church Movement in South Africa (Juta, Johannesburg, 1926), p 2; C. Nyombolo, "The Origins and Development of Ethiopianism", in E. Kamphausen, Anf ange der kirchlichen Unabhangigkeitsbewegung in Siidafrika, 1872-1912 (Lang \& Lang, Frankfurt, 1976), p 3; P. Makhubu, Who are the Independent Churches? (Skotaville, Johannesburg, 1986), pp 5-6; and H.L. Pretorius, Ethiopia Stretches out Her Hands unto God: Aspects of Transkeian Indigenous Churches (ISWEN, Pretoria, 1993), pp 4-6.

68. Government resentment of independent schools was combined with condemnation of newly established churches, whether Ethiopianist or Zionist. Some missionaries who testified to SANAC condemned teachers at independent African schools in the locations as "lazy" and not caring for education. See NASA SNA 325 NA 1644/06 NA 1768/ 06, for SANAC, Minutes of Evidence, Testimony of Rev. Farmer, p 654. See also B. Lahoule, "Ethiopianism and African Nationalism in South Africa before 1937", Cahiers d'études africaines, 26, 104, 1986, pp 681-688; P.O. Esedebe, Pan-Africanism: The Idea and the Movement, 1776-1963 (Howard University Press, Washington, 1994), pp 12-15; G. Wilmore, Black Religion and Black Radicalism: An Interpretation of the Religious History of African Americans (Maryknol, New York, 1998), pp 1-3; and J.M. Chirenge, Ethiopianism and Afro-Americans in Southern Africa, 18831916 (Louisiana State University, Baton Rouge, 1987), pp 4-6.

69. London Missionary Society (LMS), Annual Report, 1899, p 175; and Annual Report of 1904 , p 259.

70. K. Poewe and U. van der Heyden, "The Berlin Mission Society and its Theology: The Bapedi Mission Church and the Independent Bapedi Lutheran Church", South African Historical Journal, 40, 1999, p 42; G.A Duncan, "From Mission to Church: The Formation of the Bantu Presbyterian Church of South Africa", International Journal of African Historical Studies, 49, 3, 2016, p 329.

71. S.O. Samuelson (the secretary for Native Affairs) quoted in Campbell, Songs of Zion, $\mathrm{p}$ 146; PAR, SNA 1/1/377, ref. 2587, Minister for Native Affairs; and NASA SNA 325 NA 1644/06 NA 1768/ 06, SANAC Minutes of Evidence; Testimony of Rev Farmer, p 654. 
traditionalist sections in the locations that had hitherto chosen to remain aloof from Christian and school influences. ${ }^{72}$

Dr Alexander William Roberts, the acting superintendent of the Lovedale Mission, expressed a somewhat different criticism of African-led schools in his testimony at SANAC in 1905, arguing that the independent movement was "first a race movement; second ... political; third ... church, and because of the sequence, I think, it is harmful at the present day". ${ }^{73}$ In fact, African independent schools and churches troubled a number of white missionaries and government officials. One such example was a government official, Malan, who testified to the SANAC, "I should say it is the first duty of the government to know what these Natives are taught, and that they are not imbued with ideas that are detrimental to the country". ${ }^{74}$

The negative attitude of government officials and missionaries who testified against African-led schools at the SANAC hearings, influenced the state to promulgate unfavourable authorative orders in opposition to independent schools. One of the rules, Ordinance No. 5 of 1905, required that "each Native Mission School seeking financial aid from government ... [had to] be under the superintendence of a white missionary ... or other European person recognised by Government."75

This government regulation made it difficult for African independent missionary schools to be granted land and financial aid. Notwithstanding the postwar repression, isolation, and the lack of educational facilities, Africans organised themselves into formal political and religious movements that protected their interests. ${ }^{76}$

These organisations were founded in the last two decades of the nineteenth century. Amongst them were the Ethiopianist church movement, the Transvaal Native Congress (TNC), the Transvaal Vigilance Association (TVA), the Transvaal Basotho Committee (TBC) and Edward Tsewu's Iso Lomzi. All these organisations were multiethnic in composition, except, initially, for the ethnically-based TBC, which after the South African War, clarified that its concern was not limited to the circumstances suffered by the Basotho, but those of all Africans. ${ }^{77}$

72. Samuelson quoted in Campbell, Songs of Zion, p 146; PAR, SNA 1/1/377, ref. 2587, Minister for Native Affairs; and NASA SNA 325 NA 1644/06 NA 1768/ 06, SANAC, Minutes of Evidence, Testimony of Rev Farmer, p 654.

73. NASA SANAC Minutes of Evidence, Testimony of Dr Roberts quoted in J. Millard, "A Study of the Perceived Causes of Schism in Some Ethiopian-type Churches in the Cape and Transvaal", PhD thesis, University of South Africa, 1995, p 18.

74. NASA SNA 325 NA 1644/06 NA 1768/ 06, SANAC evidence, Interview between Mr Malan and the Chairman of the Commission, p 558.

75. NASA, SNA 178, Native Schools (undated).

76. See Odendaal, Vukani Bantu, pp 144-145.

77. Odendaal, Vukani Bantu, pp 144-145. 
The issues of land dispossession, education, pass laws, taxation and poor living conditions in the urban areas brought these organisations into contact with each other. They all became involved in the struggle for education but in this respect, the Ethiopianist movement played a leading role as the principal organisation that led the struggle for independent education. The Ethiopianists became the nodal point around which African educational problems and grievances were expressed. Many activists in this movement invested their political energy in a host of campaigns and struggles. They focused largely on two issues, however: education and land. ${ }^{78}$ Of the two, education for children of the urbanites was probably more fundamental to the AMEC appeal; nonetheless, the land issue seized the Africans' imagination. ${ }^{79}$

As the number of non-Christian or traditionalist urban families on the Rand increased between 1903 and 1905, the restrictions implemented by the Native Administration authorities escalated. These governmental constraints denied urban African educationists and clergymen, who formed a substantial part of urban leadership, access to urban sites where they could establish independent schools and churches in native locations. Adding to the problem, the advent of Ethiopianist independent schools and churches posed a rebellious threat on the Rand. In turn, this development deepened sectarian segregation in white-controlled mission schools. In the early 1900s, responding to broader political divisions, these schools refused to admit non-Christians if they were children from families who were members of African independent churches on the Rand. A strong relationship between some white missionaries and local authorities brought local mission schools within the ambit of the state before 1905. ${ }^{80}$ This official connection intensified local administrative measures that became increasingly hostile to the education needs of Africans in the native locations of the Rand.

These circumstances pressed Tsewu and his colleagues to wage the struggle of redressing what was seen as the hypocrisy of the ill-attended and uninspiring urban missionary schools' admission policy. Tsewu and his peers made it known that they expected the white-controlled missionary schools to respond positively to the wide range of educational needs that was being articulated by blacks on the Rand. Albeit referring to other African regions and drawing on a wider historiography, in historian Terence Ranger's words, these Africans saw the missionary establishments as "too small and too restricted of access to satisfy their aspirations" ${ }^{81}$ For Tsewu and his associates, the struggle for education was part of a social mission that encompassed not only the elite, but all Africans living in the locations. As time went by, J.Z. Tantsi

78. Higher education for Africans was limited to those in the teaching and theological fields.

79. Campbell, The Songs of Zion, $\mathrm{p} 152$.

80. S. Krige, "Segregation, Science and Commission of Inquiry: The Contestation over Native Education Policy in South Africa 1935-1936", Journal of Southern African Studies, 1997, pp 491-495; and S. Brock, "James Stewart and Lovedale: A Reappraisal of Missionary Attitudes and African Response in the Eastern Cape", PhD thesis, University of Edinburgh, 1974, pp 18-22.

81. Ranger, "African Attempts to Control Education in East and Central Africa", p 57. 
played a more prominent role in the fight for African independent education and facilitated the foundation of small independent schools in different locations on the Rand, including Klipspruit in 1906 and Boksburg in 1908, as well as others in small towns on the Rand. ${ }^{82}$ Due to the lack of official records, regrettably I am unable to provide the number of enrolments at these schools. This limitation stems from the fact that African independent schools were not registered; nor were they subsidised by the Transvaal Education Department (TED), so the government did not keep official records of these schools

As noted earlier, the parents in urban areas believed passionately that education was the only way for their children to enjoy a better life. They made strategic use of schools and took great care in selecting schools for their children. They had no choice, however, but to opt for elementary African-led schools that suffered significant constraints. As Campbell notes, the Rand was home to several AMEC-controlled subsidiary schools, a vital resource to newcomers to the city. ${ }^{83}$ They taught English and other elementary subjects such as Arithmetic and Biblical Studies, as well as subjects that assisted the newcomers to adapt better to the urban environment. The structures used by these institutes were largely dilapidated church houses that lacked proper educational facilities. Some of these buildings belonged to the municipality and the local authorities were unwilling to spend money on repairs. Due to financial constraints the independent churches themselves were unable to undertake proper repair work. ${ }^{84}$ Moreover, teachers were inadequately qualified and were of inferior capacity. They were appointed by senior church members with a view to their being catechists or evangelists assisting the missionary, all of which resulted in an inferior education. ${ }^{85}$ This situation distressed the mission-educated Africans in the locations. The problem was noted by the Native Affairs officials, as is evident in the correspondence from the acting commissioner of Native Affairs to the director of Education in 1904:

It appears that there are a certain number of native children in Johannesburg, and possibly elsewhere [on the Rand] who are practically excluded from the educational facilities at present afforded to the schools supported by government owing to the fact that their parents belong to no recognised religious denomination ... the position of these children raises the question as to whether it is desirable to recognise the principle of establishing any state native school. ${ }^{86}$

The shortage of facilities in these makeshift schools was indeed severe in the locations. It was intensified by the rapid acceleration of urbanisation. For this crucial period, it is impossible to provide reliable historical population statistics, including

82. WHP, AMethodist Episcopal Church Collection, Journal of the Proceedings of the Annual Conference of the African Methodist Episcopal Church held at Worcester, 7-12 October 1914.

83. Campbell, The Songs of Zion, $\mathrm{p} 148$.

85. Campbell The Songs of Zion, $\mathrm{p} 87$.

85. Campbell, The Songs of Zion, p 148.

86. NASA, SNA 276 NA 1588/05 NA 1686/06, Letter from the Acting Commissioner for Native Affairs, 16 November 1904. 
gender imbalances, because the Johannesburg City Council (JCC) made less effort to collect data on the black population than they did in the case of white residents on the Rand. In addition, the JCC deflected attention from the settlement patterns of those unless they were miners, migrants and men. As a result, this practice isolated the specific conditions of the urbanisation of women.

Overall, rapid mining and industrialisation before and after the South African War drove an increasing number of people who were living in rural areas to migrate towards the cities in search of improved livelihoods. As a result, the demand for schools and teachers outstripped the supply. These developments explain why nonChristian urban dwellers supported the independent school movement. Even so, perhaps the most important obstacle to the development of independent African schools was the lack of access to land. For Africans, it was necessary to buy properties because land ownership meant stability and opportunity. For black families, this gave them a shot at upward mobility and economic security for future generations. They also sought to reclaim the ownership of their traditional land and thereby honour their ancestors. This land had once been theirs but was lost in the nineteenth century to white conquest. A number of interconnected obstacles hindered Africans from opening new schools for urban children. These obstacles were comprised by the location by-laws and the discriminatory Transvaal land tenure legislation.

Thus, Tsewu's legal victory led to the foundation of African freehold areas throughout the Transvaal prior to 1913, and it paved the way for the establishment of various independent schools, including the Wilberforce Institute in 1905. Alongside Ohlange in Natal, the Wilberforce Institute - itself the subject of further detailed study - was an independent missionary school that represented remarkable evidence of self-help among missionary schools in southern Africa. These schools responded to the growing needs and pressures of a number of black children, families, and communities in the Transvaal. Like other African-led schools in the Cape and Natal, they were much more than ordinary educational institutions, because they were also the hard-earned results of the African struggle for land ownership, the African desire for black institutional leadership and educational self-determination for socioeconomic and political advancement.

\section{Conclusion}

This article has presented a new analysis of the available documentary evidence that connects both the struggle for African-led education and the quest for land rights. Neither developed merely as a reactive phenomenon. The combined struggle for African-led education and for land rights was an expression of the frustration of Africans who felt restricted by regulations that hindered them from taking the initiative and responsibility on their own. Thus, this article has deepened our understanding of this historical development.

Connections between the contestation over land and struggles over authority in South Africa have been analysed extensively in previous studies, but little is known 
about the connection between the struggle for land and the call for African independent missionary education. This is illustrated by the evidence put forward, as well as the case discussed in this article which has shown how land acquisition and education dovetailed. It also illustrates how strategies of non-violent resolution of disputes over land were adopted by the mission-educated Africans. Christianisation and literacy proved to be important mechanisms against inequality and land dispossession and, conceptually, Tsewu and his peers took the struggle for land ownership beyond local, regional, and even provincial boundaries. The influence of Cape liberalism on Tsewu opened up new opportunities for landless Christian and non-Christian Africans to buy and register land in their own names. It also created opportunities for new independent schools, most notably the Wilberforce Institute, to be built. Although many of those who established such schools were graduates from the mainstream mission schools of the Cape and Natal and in some cases American universities, they were not imposed upon from the outside.

\section{REFERENCES}

Ball, J., "Imperialism, Social Control and Colonial Curriculum in Africa", Curriculum Studies, 15, 3, (1987).

Bonner, P., Delius, P. and Posel, D. (eds), Apartheid's Genesis, 1935-62 (Ravan Press, Johannesburg, 1993).

Bonner, P., "The Transvaal Native Congress, 1917-1920: The Radicalisation of the African Petty Bourgeoisie on the Rand", in Marks, S. and Trapido, S. (eds), Industrialisation and Social Change in South Africa (Longman, London, 1982).

Bonner, P., "African Urbanisation on the Rand in the 1950s and 1960s: Its Social Character and Political Consequences", Journal of Southern African Studies, 21, 1 (1995).

Bonner, P. and Nieftagodien, N., Alexandra: A History (Wits University Press, Johannesburg, 2008).

Bozzoli, B. (ed.), Town and Countryside in the Transvaal (Ravan Press, Johannesburg, 1983).

Beinart, W.P., Delius, P. and Trapido, S. (eds), Putting a Plough to the Ground: Accumulation and Dispossession in Rural South Africa, 1850-1930 (Ravan Press, Johannesburg, 1986).

Behr, E.H., "Three Centuries of Coloured Education in the Cape and Transvaal, 16521952", PhD thesis, University of Potchefstroom, 1952.

Bergh, J., and Feinberg, H.M., "Trusteeship and Black Land Ownership in the Transvaal during the Nineteenth and Twentieth Centuries", African Historical Review, 36, 1 (2004). 
Berman, E.H., "African Response to Christian Education", African Studies Review, 17, 1974.

Braun, L.F., Colonial Survey and Native Landscapes in Rural South Africa, 1850-1913 (Brill, London, 2014).

Brock, S., "James Stewart and Lovedale: A Reappraisal of Missionary Attitudes and African Response in the Eastern Cape", PhD thesis, University of Edinburgh, 1974.

Bundy, C., The Rise and Fall of the South African Peasantry (David Philip, Cape Town, 1979).

Callinicos, L., A Place in the City: The Rand on the Eve of Apartheid (Ravan Press, Johannesburg, 1993).

Cammack, C., "The Johannesburg Republic: The Reshaping of the Rand Society, 1900 1901", South African Historical Journal, 18, 3 (1986).

Campbell, J., The Songs of Zion: The African Methodist Episcopal Church in the United States and South Africa (Oxford University Press, Oxford, 1998).

Coetzee, R.D., Bafokeng Family Law and Law of Succession (Van Schaik, Pretoria, 1990).

Chisholm, L., "Class and Colour in South African Youth Policy: The Witwatersrand, 1886-1910", History of Education Quarterly, 27, 1 (1981).

Chirenge, J.M., Ethiopianism and Afro-Americans in Southern Africa, 18831916 (Louisiana State University Press, Baton Rouge, 1987).

Cross, M., "The Foundation of Segregated Schools in the Transvaal, 1902-1924", History of Education 16, 4, 1987

Davis-Hunt, R., "Nineteenth Century African Education in the Cape Colony: A Historical Analysis", PhD thesis, University of Wisconsin, 1969.

Dlamini, J., "The Land and its Languages: Edward Tsewu and the Pre-History of the 1913 Land Act", in Cousins, B. and Walker, C. (eds), Land Divided, Land Restored: Land Reform in South Africa for the 21st Century (Jacana, Johannesburg , 2015).

De Gruchy, J.W., Christianity and the Modernisation of South Africa: A Documentary History, Volume 2 (UNISA Press, Pretoria, 2009).

Duncan, G.A., "Pull up a good tree and push it outside? The Rev Edward Tsewu's Dispute with the Free Church of Scotland Mission", NGTT, 53, 1 and 2, available at http://ngtt.journal.co.za Accessed 27 August 2018.

Duncan, G.A., "From Mission to Church: The Formation of the Bantu Presbyterian Church of South Africa", International Journal of African Historical Studies, 49, 3 (2016).

Esedebe, P.O., Pan-Africanism; The Idea and Movement, 1776-1963 (Howard University Press, Washington, 1994).

Etherington, N.A., Preachers, Peasants and Politics in South-east Africa, 1835-1880: African Christian Communities in Natal, Pondoland and Zululand (Royal Historical Society, London, 1978).

Feinberg, H.M., "Black South African Initiatives and the Land, 1913-1948", Journal of Contemporary History, 34, 2 (2009).

Fair, T.J.D. and Schmidt, C. "Contained Urbanization: A Case Study", South African Geographical Journal, 56, 2 (1974). 
Gerard, A.G., Four African Literatures: Xhosa, Sotho, Zulu and Amharic (University of California Press, Berkeley, 1971).

Hamilton, J.A., A Transvaal Jubilee: Being a History of the Church of the Province of South Africa in the Transvaal (Society for Promoting Christian Knowledge, London 1928).

Jeeves, A., Migrant Labour in South Africa's Mining Economy: The Struggle for the Gold Mines' Labour Supply, 1890-1920 (McGill-Queen's University Press, Montreal, 1995).

Keith, B., Johannesburg: The Making and Shaping of the City (UNISA Press, Pretoria, 2004).

Kagan, N., “African Settlement in the Johannesburg Area, 1903-1923", MA dissertation, University of the Witwatersrand, 1978.

Kumalo, V.R., "The African Struggle for Independent Education: A History of Wilberforce Institute, Evaton 1905 to $1950 \mathrm{~s}$ ", PhD thesis, University of the Witwatersrand, 2018.

Kumalo, V.R., "From Plough to Entrepreneurship: A History of African Entrepreneurship in Evaton", MA dissertation, University of the Witwatersrand, 2014.

Keegan, T., Rural Transformations in Industrialising South Africa: The Southern Highveld to 1914 (Macmillan, London, 1987).

Krige, S., "Segregation, Science and Commission of Inquiry: The Contestation over Native Education Policy in South Africa, 1935-1936", Journal of Southern African Studies (1997).

Lahoule, B., "Ethiopianism and African Nationalism in South Africa before 1937", Cahiers d'études africaines, 26, 104 (1986).

Lea, A., "Native Separatist Churches", in J.D. Taylor, (ed.),The Native Separatist Church Movement in South Africa (Juta, Johannesburg, 1926).

Levine, R.S., A Living Man from Africa: Jan Tzatzoe, Xhosa Chief and Missionary and Making of Nineteenth Century South Africa (Yale University Press, New Haven, 2013).

Lodge, T., Black Politics in South Africa since 1945 (Ravan Press, Johannesburg, 1983).

Loram, C.T., The Education of the South African Native (Heineman, London, 1927).

Mabin, A., "The Making of Colonial Capitalism: Intensification and Expansion in the Economic Geography of the Cape Colony, South Africa, 1854-99”, PhD thesis, Simon Fraser University, 1984.

Magubane, B.M., The Political Economy of Race and Class in South Africa (Oxford University Press, New York, 1979).

Makhubu, P., Who are the Independent Churches? (Skotaville, Johannesburg, 1986).

Mattera, D., Memory is the Weapon (African Morning Star, Johannesburg, 1987).

Morrell, R., "African Land Purchase and the 1913 Natives' Land Act in the Eastern Transvaal", South African Historical Journal, 21 (1989).

Millard, J.,"A Study of the Perceived Causes of Schism in Some Ethiopian-type Churches in the Cape and Transvaal”, PhD thesis, University of South Africa, 1995.

Murray, C., Black Mountain: Land, Class and Power in the Eastern Orange Free State, 1880s to 1980s (Edinburgh University Press, Edinburgh, 1992). 
Murray, C., "Displaced Urbanization: South Africa's Rural Slums”, African Affairs, 86 (1987).

Mweli, T.D., The African Yearly Register: An Illustrated National Biographical Dictionary (Who's Who) of the Black Folks in Africa (L. Esson, Johannesburg, 1930).

Nyombolo, C., "The Origins and Development of Ethiopianism", in Kamphausen, E. (ed.), Anf ange der kirchlichen Unabhangigkeitsbewegung in Siidafrika Geschichte und Theologie der Athiopischen Bewegung 1872-1912 (Gemenskap, Frankfurt, 1976).

Odendaal, A., Vukani Bantu: The Beginning of African Protest Politics to 1910 (David Philip, Cape Town, 1984).

Omar, I., "The Group Areas Act: A Historical and Legal Review", De Rebus, 1989,

Page, C., "Black America in White South Africa: Church and State Reaction", PhD thesis, University of Edinburgh, 1978.

Phillips, R.E., The Bantu in the City: A Study of Cultural Adjustment on the Witwatersrand (Lovedale Press, Alice, 1938).

Poewe, K., and Van der Heyden, U., "The Berlin Mission Society and its Theology: The Bapedi Mission Church and the Independent Bapedi Lutheran Church", South African Historical Journal, 40 (1999).

Pretorius, H.L., Ethiopia Stretches out Her Hands unto God: Aspects of Transkeian Indigenous Churches (ISWEN, Pretoria, 1993)

Randall, P.R., "The English Private School System in South Africa”, MA dissertation, University of the Witwatersrand, 1980.

Ranger, T., "African Attempts to Control Education in East and Central Africa, 19001939", Past and Present, 32 (1965).

Stals, E.L.P., Afrikaners in die Goudstad (Van Schaik, Pretoria, 1978).

Trapido, S., "Landlord and Tenant in a Colonial Economy: The Transvaal, 1880-1910", Journal of Southern African Studies, 5, 1 (1978).

Trapido, S., "Introduction to Reflections on Land, Office and Wealth in the South African Republic, 1850-1900", Historia, 53, 1 (2008).

Walton, J., "Early Bafokeng Settlement in South Africa”, African Studies, 15 (1956).

Wilmore, G., Black Religion and Black Radicalism: An Interpretation of the Religious History of African Americans (Maryknol, New York, 1998).

Van Onselen, C., New Babylon: New Nineveh (Johathan Ball, Johannesburg, 2001).

Van Onselen, C., The Seed is Mine: The Life of Kas Maine, a South African Sharecropper, 1894-1985 (Jonathan Ball Publishers, Johannesburg, 1996). 